\title{
The relation between the personality factors extraversion, neuroticism, general cognitive aptitude and critical thinking
} Andreea C. Buzduga 


\title{
The relation between the personality factors extraversion, neuroticism, general cognitive aptitude and critical thinking
}

\author{
Andreea C. Buzduga ${ }^{a^{*}}$ \\ a Doctoral School of Faculty of Psychology and Education Sciences, "Alexandru Ioan Cuza" University of Iași, 3 Toma Cozma Street, 700704, Iaşi, \\ Romania \\ *Corresponding author: acbuzduga@gmail.com
}

\section{Abstract}

\section{Keywords:}

critical thinking, general cognitive aptitudes, personality factors, intelligence, EPI, WGCTA
This research aimed to study the relationship between the personality factors extraversion, neuroticism, the general cognitive aptitudes and the critical thinking. The research group consisted of 709 participants, with the mean age of 19.59 years $(S D=4.72)$ of which 463 university students and 246 school students. The following tests were applied to the participants: Eysenck's Personality Inventory (EPI) form A, a Romanian version of Watson-Glaser's critical thinking test, and the East-West IQ test for evaluating the general intelligence. As far as the Introversion-Extraversion dimension is concerned, our results $(p<0.001)$ showed that the introverted participants have significant better results at the critical thinking test. Participants who scored low on neuroticism had significantly higher scores $(p<0.001)$ on the critical thinking variable compared to those who had high scores for the neuroticism variable. Significant differences had been observed between different levels of IQ and critical thinking. There is also a significant relationship $(r=0.31 ; p<0.001)$ between the age of the participants and the result on critical thinking. The conclusions lead to the possibility of highlighting the importance of some personal aspects, as personality, in order to identify the potential to achieve a reasonable (focused on compare and decide) way of thinking.
Zusammenfasung

\section{Schlüsselworte:}

kritisches Denken, allgemeine kognitive Fähigkeiten, Persönlichkeitsfaktoren, Intelligenz, EPI, WGCTA
Diese Forschung hat dem Ziel, die Beziehung zwischen der Persönlichkeit Faktoren Extravertiertheit, Neurotizismus, die allgemeinen kognitiven Fähigkeiten und das kritische Denken zu studieren. Die Forschungsgruppe bestand aus 709 Teilnehmern, mit dem Durchschnittsalter von 19,59 Jahren (Standardabweichung = 4,72), von denen 463 Studenten und 246 Schüler. Die folgenden Tests wurden an die Teilnehmer angewandt: Eysencks Personality Inventory (EPI) Form A, eine rumänische Version von Watson-Glaser kritischen Denken Test und der Ost-West-IQ-Test für die Auswertung der allgemeinen Intelligenz. Soweit die Introversion-Extraversion Dimension betrifft, unsere Ergebnisse $(p<0,001)$ zeigten, dass die introvertierten Teilnehmer signifikant bessere Ergebnisse bei dem kritischen Denken Test haben. Die Teilnehmer, die niedrig auf Neurotizismus erzielt hatten signifikante höhere Werte $(\mathrm{p}<0,001)$ auf der kritische-Denken-Variable im Vergleich zu denen, die für die Neurotizismus-Variable hohe Werte hatten. Signifikante Unterschiede waren zwischen den verschiedenen Ebenen von IQ und kritisches Denken beobachtet. Es gibt auch eine signifikante Beziehung $(\mathrm{r}=0,31 ; \mathrm{p}<0,001)$ zwischen dem Alter der Teilnehmer und dem Ergebnis auf kritisches Denken. Die Schlussfolgerungen führen zu der Möglichkeit, die Bedeutung einiger persönlichen Aspekte - als Persönlichkeit - hervorheben, um das Potenzial zu identifizieren, um eine angemessene Denkweise zu erreichen (Schwerpunkt vergleichen und entscheidet).

\section{Introduction}

The worldwide phenomenon named critical thinking, has been listed in the education field as an important asset to be cultivated in countries like United States, United Kingdom, Australia or Romania (Ciascai \& Haiduc, 2009). Similarly, Asian countries like Hong Kong and Japan, had suggested the development of critical thinking for the future education of the student in the liberal society spirit $(\mathrm{Ku}$, 2009). According to the Romanian Ministry of Education, Research, Youth and Sports (2018), critical thinking is founded at lyceum upper cycle, on the history curriculum, as a general skills, value and attitudes area, associated with the reflective thinking. Thus, on the social science area, proponents remembered the necessity of forming and developing the critical thinking skills through developing self-consciousness by internalizing the values of democratic citizenship and value-related relationships with other community members - school, local, national, European level; Moreover, within philosophy the need for critical thinking is justified as a tool necessary for students to develop their own system of values, the cognitive potential and the cultural horizon formed in previous years of study. The main purpose of this research was to explore 
the relationship between critical thinking and personality factors (as extraversion and neuroticism), but also between the first aforementioned variable and the general cognitive aptitudes.

Despite the lack of agreement in defining the critical thinking, the numerous specific definitions presented a significant overlap. The intellectually engaged, responsible and very skilful thinking is named critical thinking. This leads to a better judgment, based on the application of assumptions, competence, knowledge, and the ability to keep under control one's own thinking (Niu, BeharHorenstein \& Garvan, 2013). Critical thinking skills allow students a careful and fast assimilation of a subject-specific content in any discipline and provide the ground that allows students to be engaged in offering solutions to definite problems (Tsui, 2000; Butler, Pentoney \& Bong, 2017). Hence, critical thinking skills are important for students in order to perform well at school, but also for their future work performance, and in social and interpersonal context, where daily decisions have to be made independently on a main basic understanding worldwide (Ku, 2009; Gunn, Grigg \& Pamahac, 2007). The critical thinking is wide known in the adult education field for its practical implication in the professional and personal development as a lifelong process of learning. In conclusion, the superior level of thinking can be defined as critical thinking formed in personality dispositions and skills.

Researching the scientific literature about the importance of personality disposition for understanding how individual ability to think critically differs, we find only few studies as Clifford, Boufal \& Kurtz (2004); an exploratory study where the researchers applied the Five Factor Model of personality to the disposition model of critical thinking to find which personality traits can predict the critical thinking performance. The results revealed that Openness to Experience explained $11.8 \%$ of the critical thinking variance. Instead, the theoreticians offer qualitative studies in which they describe the personality traits of a critical thinker (Beyer, 1995; Paul, 1992).

In the continuous search of a response for "what constitutes the critical thinking", philosophers and psychologists had different beliefs about the acquisition of the skills needed, as a developmental process regulated by motivations, personality traits and dispositions.

Over the years many studies have shown that IQ scores are related with academic success and the academic achievement is related with critical thinking (Burbach,
Matkin, \& Fritz, 2004; Aksu \& Koruklu 2015; Nusbaum \& Silvia, 2011; Katrevich \& Aruguete, 2017). Nonetheless, based on the hypothesis proposed by a number of researchers, the intelligence and critical thinking may be the same construct due to their higher correlation (McPeck, 1990). Though, Elder' s research (1996) revealed the fact that intelligence and critical thinking are independent constructs. Other empirical studies show that critical thinking skills do not depend on the cognitive ability. Equally, Macpherson and Stanovich (2007) argued that cognitive ability is not a sustained predictor for the critical thinking. This was the base for our study, to investigate if the intelligence is related to the critical thinking, using two instruments of measuring (Eysenck Personality Inventory and Watson-Glaser Critical Thinking Appraisal), adapted to the Romanian specific culture.

\section{Method}

\subsection{Participants and procedures}

University students and secondary school students $(\mathrm{n}=$ 709) from the city of Iasi took part in this research (34,7\% secondary school students, $65,3 \%$ university students). A majority of the sample was female $(87,2 \%)$. The participants ranged in age from 14 to 50 years old $(\mathrm{M}=$ $19.59, \mathrm{SD}=4.72)$. The secondary school students were recruited from their Information and Communication Technology classes at a large public college and received participation credit as compensation. The university students were recruited from History of Psychology, Fundamentals of Psychology and Personality Psychology classes at a large public university and they also received participation credit as compensation.

\subsection{Instruments and procedures}

The participants completed a personality assessment inventory, a cognitive aptitude test, and a critical thinking test. All of these data were collected online. The university students were asked to take as many breaks as needed between measures, but to complete all the measures within the same day. The secondary school students completed the assessments in two steps, first, the critical thinking test and the personality assessment and second the cognitive aptitude test. The initial sample size was 791 , but 82 participants were excluded either because they did not complete all three assessments, or they scored three standard deviations over or below the mean on one or more of the assessments. 


\subsubsection{Personality assessment inventory}

The Eysenck Personality Inventory (EPI), a Romanian unpublished translated version, was used to measure the two broad dimensions of personality, ExtraversionIntroversion and Neuroticism-Stability, with an additional Lie scale. We calculated the reliability through Cronbach's Alpha coefficient and the results are 0.72 (ExtraversionIntroversion) and 0.82 (Neuroticism-Stability). We verified the partial correlation controlling the age and the results showed a statistically significant $(p<.001)$ between Extraversion-Introversion and Critical Thinking zero-order correlation showed -0.20 , and -0.17 for NeuroticismStability beside a significant $(\mathrm{p}<.001)$ age influence of $0.30(\mathrm{p}<.001 ;$ rECT.age $=0.23)$.

The instruments are composed of 57 "yes" or "no" items, according to the Hans J. Eysenck personality theory.

\subsubsection{Cognitive Aptitude Test}

The East - West IQ test (Sava, Constantin, Măricuțoiu, Rusu, 2014) short version was used to measure the fluid intelligence, the crystallized intelligence and the visual processing. EVIQ-S is based on the Cattell-Horn-Carroll hierarchical intelligence model and it has 30 items with multiple choice questions. The test range was assigned as follows: lower IQ, low IQ, medium IQ, high IQ, higher IQ, and very higher IQ. The authors report the split-half internal consistency corrected by Spearman- Brown with values between 0.82 and 0.90 .

\subsubsection{Critical Thinking Test}

The Watson-Glaser Critical Thinking Appraisal (WGCTA) was used to measure critical thinking skills. The test has 81 items that were adapted for the Romanian cultural specific, split into five sections, each assessing a particular skill; as inference, recognition of assumptions, deduction, interpretation and evaluation of arguments. WGCTA includes multiple choice questions and "yes" or "no" items. The main manual reports corrected split-half reliability coefficients ranging from 0.69 to 0.85 (Watson \& Glaser, 1980, cited in Clifford et al., 2004, p. 171).

\section{Results}

The purpose of this research was to explore the relationship between the personality factors extraversion, neuroticism and critical thinking, the general cognitive aptitudes and the ability to think critically. The pattern of the results was similar for university students and secondary school students.

The one-way analysis of variance (ANOVA) revealed a significant effect $\mathrm{F}(2,706)=14.126, \mathrm{p}<.001$ for introverts $(\mathrm{M}=48.82 ; \mathrm{SD}=5.66)$ which had better outcomes on critical thinking than extravert $(\mathrm{M}=45.30 ; \mathrm{SD}=6.37)$ and ambivert participants $(\mathrm{M}=46.80 ; \mathrm{SD}=6.08)$.

The Independent Samples T-test revealed a significant difference $t(707)=3.76, p<.001$ on the stability variable for the participants $(\mathrm{M}=48.04 ; \mathrm{SD}=6.04)$ obtaining better outcomes on critical thinking than on neuroticism $(\mathrm{M}=$ 46.21; $\mathrm{SD}=6.17)$

For the intelligence variable the ANOVA one-way analysis revealed a significant effect $\mathrm{F}(5,703)=16.736$, $\mathrm{p}$ $<.001$ for the participants with very high IQ $(\mathrm{M}=52.36$; $\mathrm{SD}=5.73$ ) who had better outcomes on critical thinking than for the participants with a lower IQ $(\mathrm{M}=37.63$; $\mathrm{SD}=$ 5.63), low IQ $(\mathrm{M}=43.47$; $\mathrm{SD}=6.86)$, medium IQ $(\mathrm{M}=$ 45.89; $\mathrm{SD}=6.01)$, high IQ $(\mathrm{M}=48.01 ; \mathrm{SD}=5.33)$ and higher IQ $(\mathrm{M}=49.75$; $\mathrm{SD}=5.98)$.

A Pearson correlation was computed to assess the relationship between the participants' age and the critical thinking outcomes. The analysis revealed that there was a small and positive but statistically significant correlation $r$ $(709)=0.31, p<.001$ between age and the critical thinking outcomes. These results support the hypothesis that age can influence the critical thinking.

\section{Discussion}

The main goal of our study was to examine how critical thinking relates with personality factors (extraversion and neuroticism) and with intelligence.

Overall, our study supports the literature that the introvert participants tend to have the best outcomes on critical thinking. These results are explained by the Eysenck's theory in which the introvert persons tend to dedicate their time to studying and that they are habituated to think more than the extroverted persons who prefer to spend more time being with others and socializing. Moreover, the emotional stable participants had significant better results in critical thinking. These results are also consistent with Rammstedt, Danner and Martin (2016) and Eysenck's description of an emotional stable person, as well adapted to the social life, peaceful in any situation, who deals with unforeseen situations through a high self- 
confidence. Also, many researchers (DeNitto \& Strickland, 1987; Zechmeister \& Johnson, 1992; Facione et al., 1994; Halpern, 1998) framed the personality trait of a critical thinker, under the dimension of conscientiousness, such as the diligence, carefulness, systematic problem-solving styles and need for order.

In addition, our results showed that the participants with a very high IQ level, had the best critical thinking, results supported by Clifford, Boufal and Kurtz (2004).

Finally, several limitations should be mentioned. Our research is exploratory, and the results do not lend themselves to any deeper interpretations. Future studies could research the possibility of predictive models for a better critical thinking. The significant positive correlation found between age and the critical thinking does not provide evidence for causal connections between these variables. Longitudinal studies with more detailed observations should be conducted in order to understand the critical thinking concept. Our future research will focus on the importance of the participants' age in the relationship between the personality and the critical thinking.

Despite these limitations, the current findings advance the critical thinking literature on exploring the relationship between personality variables and the cognitive aspects as critical thinking, measured with instruments adapted to the Romanian specific culture.

Our current investigation offers some insights into the relationship between personality (measured by the Personal Inventory of Eysenck) and critical thinking and the same variable and intelligence. Our future direction will be an investigation of the importance of the participants' age in the relationship between personality and critical thinking. We are keen to provide an understanding of how personality influences the critical thinking once the age increases.

\section{Acknowledgments}

This article was presented at The Fifth International Conference on Adult Education 2018, Iași, Romania.

\section{Authors note:}

Buzduga C. Andreea is currently a Ph.D. student at Faculty of Psychology and Education Sciences, "Alexandru Ioan Cuza" University of Iași. Research interests in critical thinking, developing critical thinking and teaching methods.

\section{References}

Aksu, G. \& Koruklu, N. (2015). Determination the Effects of Vocational High School Students' Logical and Critical Thinking Skills on Mathematics Success. Eurasian Journal of Educational Research, 59, 181-206.

Beyer, B.K. (1995). Critical thinking. Bloomington, In: Phi Delta Kappa Educational Foundation.

Burbach, M. E., Matkin, G.S. \& Fritz, S.M. (2004). Teaching critical thinking in an introductory leadership course utilizing active learning strategies: A confirmatory study. College Student Journal, 38(3), 482.

Butler, H.A., Pentoney, C. \& Bong, M.P. (2017). Predicting realworld outcomes: Critical thinking ability is a better predictor of life decisions than intelligence. Thinking Skills and Creativity, 25, 38-46.

Ciascai, L. \& Haiduc, L. (2009). Is Romanian Science School Curricula Open towards the Development of School Students' Critical Thinking Skills? Acta Didactica Napocensia, 2(3), 918.

Clifford J.S., Boufal M. M., \& Kurtz J.E. (2004). Personality Traits and Critical Thinking Skills. In College Students: Empirical Tests of a Two-Factor Theory. Assessment, 11(2), $169-176$.

DeNitto, J. \& Strickland, J. (1987). Critical thinking: A skill for all seasons. College Student Journal, 21, 201-204.

Elder, L. (1996). Critical thinking and emotional intelligence. Inquiry: Critical thinking across the disciplines, 16(2), 35-49.

Facione, N.C. Facione, P.A. \& Sanchez, C.A. (1994). Critical thinking disposition as a measure of competent clinical judgment: The development of the California Critical Thinking Disposition Inventory. Journal of Nursing Education, 33, 345350.

Gunn, T., Grigg, L. \& Pomahac, G. (2008). Critical Thinking in Science Education: Can Bioethical Issues and Questioning Strategies Increase Scientific Understandings? The Journal of Educational Thought (JET) / Revue de la Pensée Éducative, Vol. 42, No. 2, SPECIAL ISSUE. Calgary: Werklund School of Education, University of Calgary.

Halpern, D.F. (1998). Teaching critical thinking for transfer across do- mains: Dispositions, skills, structure training, and metacognitive monitoring. American Psychologist, 53, 449455.

Henderson Hurley, M. \& Hurley, D. (2013). Enhancing Critical Thinking Skills among Authoritarian Students. International Journal of Teaching and Learning in Higher Education, 25(2), 248-261.

Katrevich, A.V. \& Aruguete, M.S. (2017). Recognizing Challenges and Predicting Success in First-Generation University Students. Journal of STEM Education: Innovations and Research, 18(2), 40-44. 
Ku, K.Y.L. (2009). Assessing students' critical thinking performance: Urging for measurements using multi-response format. Thinking Skills and Creativity, 4(1), 70-76.

Macpherson, R. \& Stanovich, K.E. (2007). Cognitive ability, thinking dispositions, and instructional set as predictors of critical thinking. Learning and individual differences, 17(2), 115-127.

McPeck, J.E. (1990). Teaching critical thinking: Dialogue and dialectic. Routledge.

Niu, L., Behar-Horenstein, L.S. \& Garvan, C.W. (2013). Do instructional interventions influence college students' critical thinking skills? A meta-analysis. Educational Research Review, 9, 114-128.

Nusbaum, E.C. \& Silvia, P.J. (2011). Are intelligence and creativity really so different? Fluid intelligence, executive processes, and strategy use in divergent thinking. Intelligence, 39(1), 36-45.

Rammstedt, B., Danner, D. \& Martin, S. (2016). The association between personality and cognitive ability: Going beyond simple effects. Journal of Research in Personality, 62(Supplement C), 39-44.

Sava, F.A., Constantin, T., Măricuțoiu, L.P., Rusu, A. (2014). Proba EVIQ-S de evaluare a inteligenței generale, Timișoara: Editura ArtPress.
Steward, R.J. \& Al-Abdulla, Y. (1989). An Examination of the Relationship between Critical Thinking and Academic Success on a University Campus. Reports - Research/Technical. Retrieved from https://files.eric.ed.gov/fulltext/ED318936.pdf. Stanovich, K.E., \& West, R.F. (2008). On the failure of cognitive ability to predict my side and one-sided thinking biases. Thinking \& Reasoning, 14(2), 129-167.

Tsui, L. (2000). Effects of Campus Culture on Students' Critical Thinking. The Review of Higher Education, 23(4), 421-441.

Walker, J., Langan, E., Kemp, A., Pagnotti, J. \& Russell, W. (2016). Theoretical Cognitive Principles Observed in the Social Studies Classroom. Journal of International Social Studies, 6(1), 143-159.

Watson, G. (1980). Watson-Glaser critical thinking appraisal. San Antonio, TX: Psychological Corporation.

Zechmeister, E.B. \& Johnson, J.E. (1992). Critical thinking: A functional approach. Pacific Grove, CA: Brooks/Cole.

Ministerul Educaţiei, Cercetării, Tineretului şi Sportului (2018). Aria curriculară Om şi societate - Proiecte de programe şcolare pentru clasa a XII-a (în vigoare începând cu anul şcolar 20072008). [online] edu.ro. Available at: http://oldsite.edu.ro/index.php/articles/6916 [Accessed 9 Jan. 2018]. 